\title{
ZRÓŻNICOWANIE DOCHODÓW A EFEKTYWNOŚĆ RYNKU PRACY NA PRZYKŁADZIE WYBRANYCH KRAJÓW OECD
}

\begin{abstract}
Streszczenie
Celem artykułu jest zaprezentowanie oraz próba weryfikacji hipotezy, zgodnie z która społeczeństwo musi dokonywać wyboru pomiędzy ograniczaniem nierówności dochodowych a efektywnością rynku pracy, przejawiająca się niskim poziomem bezrobocia i wysokim zatrudnieniem. Tak sformułowana hipoteza została wykorzystana przez Paula Krugmana do objaśnienia uwarunkowań funkcjonowania rynków pracy w USA i w Europie w połowie lat dziewięćdziesiątych XX wieku. Dowodził on wówczas, że negatywne szoki gospodarcze skutkują w krajach europejskich wzrostem bezrobocia, natomiast w USA wzrostem rozpiętości płac. Tymczasem odmienność reakcji wynika w głównej mierze ze zróżnicowania poziomu elastyczności rynku pracy, w tym przede wszystkim płac. W związku z tym, że hipoteza Paula Krugmana jest wciąż stosunkowo popularna, warto podejmować kolejne próby jej weryfikacji. W dotychczas prowadzonych badaniach jest powszechna dyskusja na temat przyczyn obserwowanego wzrostu zróżnicowania dochodów w większości społeczeństw, w której analizie są poddawane najczęściej takie zjawiska, jak: liberalizacja handlu międzynarodowego, postęp technologiczny promujący wysokie kwalifikacje (Skill-Biased Technical Change - SBTC) oraz deregulacja rynku pracy. Jednakże w badaniach tych stosunkowo rzadko dokonuje się empirycznej oceny związku pomiędzy zróżnicowaniem dochodów w społeczeństwie a warunkami funkcjonowania rynku pracy.
\end{abstract}

Słowa kluczowe: zróżnicowanie dochodów, bezrobocie, hipoteza P. Krugmana

\section{INCOME INEQUALITY AND EFFICIENCY OF LABOUR MARKET}

\section{Summary}

The purpose of this paper is to present and test the hypothesis that every society has to make a choice between the limitation of income inequality, on the one hand, and labour market efficiency understood as low level of unemployment and high employment, on the other hand. This hypothesis was used by P. Krugman in mid 1990s to explain the performance of labour markets in the U.S. and Europe. He argued that negative economic shocks led to higher unemployment in Europe, whereas in the U.S. to greater income inequality. The different response to shocks is mainly due to the diversity of labour market flexibility, above all wage flexibility. Since Krugman`s hypothesis is still well-known, it is reasonable to re-examine it. Generally, a trend towards greater income inequality has been indicated in a number of studies. There has been considerable discussion of the factors related to this phenomenon, usually with emphasis on: liberalisation of international trade, skill-biased technical change - SBTC, labour market deregulation. However, only in a few studies economists take into consideration the correlation between unemployment (employment) rates and income inequality.

Key words: income inequality, unemployment, P. Krugman`s hypothesis

\footnotetext{
${ }^{1}$ dr Anita Szymańska - Wydział Ekonomiczny, Uniwersytet Gdański; e-mail: anitas@gnu.univ.gda.pl.
} 


\section{Wstęp}

Efektywność rynku pracy, przejawiająca się przede wszystkim niskim bezrobociem i zdolnością do kreacji miejsc pracy, jest przedmiotem zainteresowania wielu ekonomistów. W poszukiwaniu determinant tej efektywności analizuje się wiele czynników i podejmuje się próby oceny siły i kierunku ich oddziaływania. Zadanie to jest niezwykle trudne ze względu na różnorodność i zmienność analizowanych czynników. Zróżnicowanie dochodów jest jednym $z$ tych, którego wpływ na warunki funkcjonowania rynku pracy jest szczególnie trudny do oszacowania.

Celem artykułu jest zaprezentowanie oraz próba weryfikacji hipotezy, zgodnie z która społeczeństwo musi dokonywać wyboru pomiędzy ograniczaniem nierówności dochodowych a efektywnością rynku pracy. W prowadzonych badaniach zazwyczaj analizuje się obserwowany, w większości społeczeństw, wzrost zróżnicowania dochodów, jak również prowadzi się dyskusję na temat przyczyn tego wzrostu. Jednakże tylko w nielicznych przypadkach dąży się do ustalenia związku pomiędzy zróżnicowaniem dochodów w społeczeństwie a warunkami funkcjonowania rynku pracy.

\section{Założenia teoretyczne}

Arthur Okun, publikując w 1975 roku swoją monografię pt: Equality and Efficiency: The Big Tradeoff [Okun, 1975], stał się popularyzatorem hipotezy, według której jednym z nieuniknionych wyborów, dokonywanych w gospodarce rynkowej, jest wybór pomiędzy równością a efektywnością. Według Okuna, istnieje konflikt pomiędzy społeczna potrzebą redukcji zbyt dużych nierówności ekonomicznych wśród obywateli a efektywnościa gospodarki. Dążenie do zwiększania egalitaryzmu ekonomicznego odbywa się zgodnie z tą hipoteza, kosztem zdolności gospodarki do rozwoju.

The Big Tradeoff (związany z rynkiem pracy) dotyczy wyboru pomiędzy ograniczaniem nierówności dochodowych w społeczeństwie a efektywnością rynku pracy przejawiająca się niskim poziomem bezrobocia i wysokim zatrudnieniem. Innymi słowy, społeczeństwo staje przed trudnym wyborem pomiędzy sprawnie działającym rynkiem pracy i akceptacją stosunkowo dużych rozpiętości dochodowych a ograniczeniem nierówności dochodowych, w tym eliminowaniem ubóstwa, jednak kosztem wyższego poziomu bezrobocia.

Uzasadnienie tak sformułowanej hipotezy wywodzi się z założeń teorii neoklasycznej, opartych na przekonaniu o skuteczności naturalnych mechanizmów rynkowych prowadzących gospodarkę, w tym również rynek pracy, do stanu równowagi. Jednakże osiagnięcie stanu równowagi jest możliwe wtedy, gdy siły rynkowe działają w sposób nieskrępowany, tzn. procesy dostosowawcze zachodzą w warunkach braku ograniczeń zarówno ilościowych, jak i cenowych. Wówczas to rynek pracy zmierza do osiagnięcia stanu równowagi, charakteryzującego się odpowiednią ilością i ceną (płaca) równowagi. Natomiast w sytuacji, gdy np. płace nie będą mogły dostatecznie elastycznie reagować na zmiany zachodzące na rynku pracy (np. spadek popytu na pracę), może dojść do za- 
burzeń funkcjonowania tego rynku, przejawiającego się wzrostem poziomu bezrobocia [Kwiatkowski, 2002, s. 101].

Przedstawione uzasadnienie stało się podstawą hipotezy Paula Krugmana sformułowanej w połowie lat dziewięćdziesiątych XX wieku, zgodnie z którą negatywne szoki gospodarcze skutkuja w krajach europejskich wzrostem bezrobocia ${ }^{2}$, natomiast w Stanach Zjednoczonych wzrostem rozpiętości płac. Stwierdza on, że wzrost rozpiętości płac w Stanach Zjednoczonych i wzrost bezrobocia w Europie to „dwie strony tego samego medalu". Rozpiętość dochodowa w gospodarce amerykańskiej, przy jednocześnie stosunkowo niskim bezrobociu, jest dowodem na to, iż wysoka elastyczność płac pozwala na akomodację szoków gospodarczych bez daleko idących redukcji w poziomie zatrudnienia. Tymczasem w gospodarkach, charakteryzujących się mniejszą elastycznością instytucji rynku pracy, odpowiedzią na zakłócenia gospodarcze jest wzrost bezrobocia. Występuje swoistego rodzaju kolizja pomiędzy polityka państwa dobrobytu, której zadaniem jest przede wszystkim ograniczanie nierówności dochodowych w społeczeństwie, a siłami rynkowymi, które popychają rynek pracy w kierunku wzrostu dyspersji płac. Im bardziej państwo, przeciwdziałając siłom rynkowym pogłębiającym nierówności dochodowe, będzie próbowało te nierówności ograniczać (np. przez zwiększanie zasiłków dla bezrobotnych), tym wzrost bezrobocia może być większy na skutek zmniejszającej się różnicy pomiędzy wysokością płacy możliwej do uzyskania na rynku a wysokością dochodu oferowanego przez państwo. Odnosi się to w szczególności do pracowników nisko opłacanych. Odmienność reakcji rynków pracy na szoki gospodarcze, jak podkreśla Paul Krugman, wynika z odmienności systemów instytucjonalnych, funkcjonujących w poszczególnych gospodarkach. Akceptacja dla dużych rozpiętości dochodowych jest ceną płaconą za niski poziom bezrobocia [Krugman, 1994, s. 23-43]. W zwiazzku z tym, że hipoteza Paula Krugmana jest wciąż stosunkowo popularna, jakkolwiek nie została ona ostatecznie potwierdzona przez badaczy, warto podejmować kolejne próby jej weryfikacji.

\section{Charakterystyka rozpiętości dochodowych}

W analizach nierównomierności w rozkładzie dochodów wykorzystuje się wiele różnych mierników uwzględniających rozmaite zmienne (płace, całkowite dochody, przed lub po opodatkowaniu, z uwzględnieniem bądź nie transferów socjalnych, dochody powiększone o dochody z kapitału itd.) w odniesieniu do różnorodnych grup społecznych (ogół ludności, ludność w wieku produkcyjnym, pracujący, osoby indywidualne lub gospodarstwa domowe). Najczęściej wykorzystywanymi miernikami są decylowe współczynniki rozpiętości dochodów oraz współczynnik Giniego (miara koncentracji), nieco rzadziej: wariancja dochodów, miara Atkinsona, uogólnione miary entropii $\mathrm{i}$ inne.

\footnotetext{
${ }^{2}$ Chodzi tu przede wszystkim o wzrost bezrobocia strukturalnego (utożsamianego z bezrobociem naturalnym), którego wartość jest zmienna i może wzrosnąć na skutek negatywnego szoku gospodarczego w wyniku zjawiska histerezy.
} 
Najprostszą miarą nierównomierności w rozkładzie dochodów, stosowaną w porównaniach międzynarodowych, jest współczynnik decylowy. Najczęściej oblicza się iloraz skrajnych grup decylowych wartości cechy - D9/D1, który określa relację między najwyższym (granicznym) dochodem w dziewiątej grupie decylowej (D9) a najwyższym (granicznym) dochodem w pierwszej grupie decylowej (D1). Wzrost rozpiętości dochodów znajduje wyraz we wzroście wartości wskaźnika. Ponadto, analizie poddaje się wskaźniki D9/D5 oraz D5/D1 (gdzie D5 oznacza medianę - dochód środkowy, czyli najwyższy poziom dochodów w piątej grupie decylowej). Wzrost wartości tych wskaźników również wskazuje na wzrost zróżnicowania dochodów. Zmiany w rozpiętości dochodów na ogół są konsekwencją zmian w dwóch subkategoriach dochodowych, tzn. zmian w nierównościach pomiędzy grupą o najwyższych dochodach a mediana (D9/D5) oraz pomiędzy medianą a grupa o najniższych dochodach (D5/D1), [Makać, Urbanek-Krzysztofiak, 2008, s. 67-69].

Współczynnik Giniego jest liczbową miarą koncentracji (nierównomierności) rozkładu zmiennej losowej, wykorzystywaną w statystyce opisowej. Współczynnik przyjmuje wartości od 0 do 1 , gdzie 0 oznacza całkowity brak koncentracji wartości cechy wśród jednostek zbiorowości (każdej jednostce przypada wartość cechy równa średniej arytmetycznej), a 1 oznacza, że jedna jednostka dysponuje całą wartością badanej cechy. Im wyższa jest wartość współczynnika Giniego, tym nierówności dochodowe w społeczeństwie (w badanej zbiorowości) są wyższe. Współczynnik ten jest wrażliwy na zmiany wartości cechy w środkowej części rozkładu wartości, natomiast niezbyt dobrze odwzorowuje zmiany na skrajach rozkładu wartości cechy [Kuszewski, 2008, s. 159-161].

Nierównomierności w rozkładzie dochodów stanowią przedmiot wielu analiz ekonomicznych, najczęściej dokonuje się porównań międzynarodowych oraz poddaje się obserwacji zmiany zachodzące w czasie. Jedno z istotnych pytań, na które poszukuje się odpowiedzi, odnosi się do zmian w strukturze rozkładu dochodów prowadzacych do wzrostu ich rozpiętości. Wzrost ten najczęściej jest spowodowany wzrostem dochodów, odnotowanym w grupach znajdujących się na szczycie „drabiny dochodowej” lub/i spadkiem dochodów w grupach, które znajdują się na jej dole.

$\mathrm{Na}$ rysunku 1. przedstawiono trzy różne sytuacje, w których dochodzi do wzrostu rozpiętości dochodów. Kolumny, oznaczone symbolem T1, obrazują sytuację wyjściową. Kolumny, oznaczone symbolem T2, ilustrują sytuacje, w których rozkład dochodów w społeczeństwie uległ zmianie. W pierwszym przypadku - collapsing bottom - następuje spadek dochodów uzyskiwanych przez grupy najuboższe. W drugim - flying top - grupy najbogatsze zaczynają osiagać jeszcze wyższe dochody (lub ich dochody wzrastają szybciej niż to ma miejsce w innych grupach), w trzecim zaś - polarization - maja miejsce oba wymienione zjawiska. 


\section{Modele zmian rozpiętości dochodów}

\section{RYSUNEK 1.}

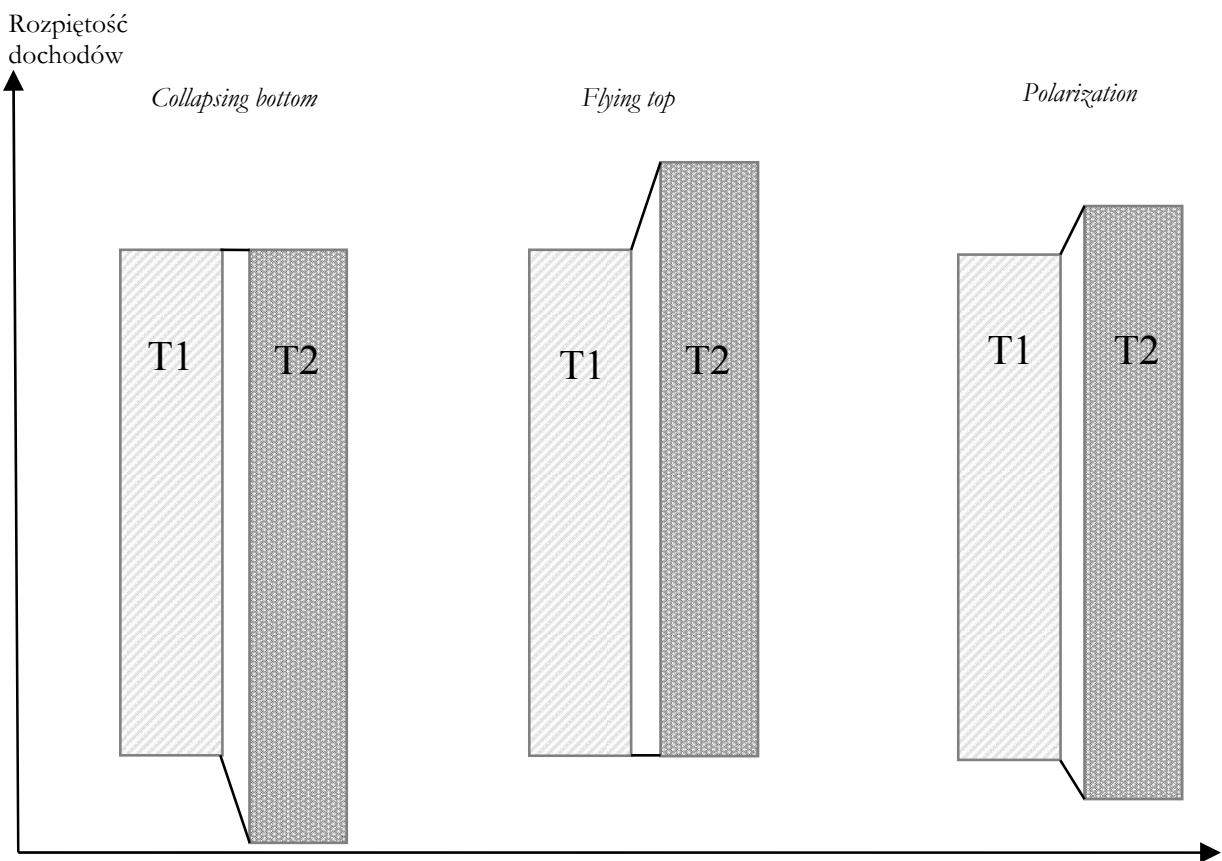

Źródło: [Global Wage Report 2008/09. Minimum wages and collective bargaining: Towards policy coberence, 2008, s. 25].

Inną, często spotykaną sytuacja, obrazującą nierównomierność rozkładu dochodów, jest rozkład określony przez Hansa W. Sinna jako „efekt akordeonu”. Efekt taki występuje wówczas, gdy dochody, znajdujące się poniżej mediany, są zróżnicowane w znacznie mniejszym stopniu niż te powyżej mediany (są ściśnięte, skompresowane), [Möller, 2009, s. 43].

\section{Przyczyny obserwowanych tendencji}

Niezależnie od sposobu pomiaru zróżnicowania dochodów, główną determinanta zmian ich poziomu są zmiany wynagrodzeń, które według szacunków stanowią około $75 \%$ dochodów gospodarstw domowych wśród ludności w wieku produkcyjnym [Divided We Stand..., 2011, s. 22]. W literaturze ekonomicznej często jest podejmowana dyskusja na temat możliwych przyczyn wzrostu zróżnicowania dochodów. Wśród nich najczęściej wymienia się:

- globalizację; 
- $\quad$ postęp technologiczny promujący wysokie kwalifikacje (Skill-Biased Technical Change - SBTC), związany ze zmianami struktury popytu globalnego polegającymi na wzroście zapotrzebowania na produkty i usługi, które mogą być wytwarzane jedynie z udziałem wysoko wykwalifikowanej siły roboczej;

- $\quad$ politykę gospodarczą prowadzoną w poszczególnych państwach, zwłaszcza zakres regulacji rynku pracy i rynku towarów i usług.

Najczęściej jest rozważany wpływ globalizacji, zaś w szczególności procesów związanych z liberalizacją handlu międzynarodowego, na kształtowanie się rozkładu dochodów w społeczeństwie. Zazwyczaj uważa się, że procesy te wywołują wzrost rozpiętości dochodowych. Jednak należy podkreślić , że dowody w tym zakresie nie są jednoznaczne, a metody badania wpływu handlu międzynarodowego na rynek pracy wywołują liczne dyskusje wśród ekonomistów [Cornia, Court, 2001, s. 17-18]. Zgodnie z tradycyjną teorią wymiany międzynarodowej, wzrost integracji gospodarczej prowadzi do wzrostu relatywnego poziomu wynagrodzeń dla wykwalifikowanych pracowników w krajach o wysokim poziomie rozwoju gospodarczego, przyczyniając się tym samym do wzrostu rozpiętości dochodowych w tych krajach [Kremer, Masking, 2006, s. 6-11]. Wraz ze wzrostem stopnia otwarcia gospodarki powiększają się nierówności dochodowe pomiędzy wysoko i nisko wykwalifikowanymi pracownikami. Może również dojść do wzrostu bezrobocia w sektorach produkujących dobra, które na skutek liberalizacji wymiany międzynarodowej są zastępowane dobrami importowanymi, oraz do wzrostu zatrudnienia w branżach produkujących dobra eksportowe.

Postęp technologiczny, promujaccy wysokie kwalifikacje, jest czynnikiem wzmacniajaccym gwałtowny wzrost zapotrzebowania na pracowników o wysokich kwalifikacjach przy jednoczesnym niedostatku tych pracowników, co bezpośrednio prowadzi do wzrostu wynagrodzeń w tej grupie, jednocześnie powodując relatywne obniżenia poziomu wynagrodzeń w pozostałych grupach pracowników. Przede wszystkim wskazuje się, iż mechanizm tego typu miał miejsce w latach osiemdziesiątych i na początku dziewięćdziesiątych XX wieku w Stanach Zjednoczonych i w Wielkiej Brytanii [Gottschalk, Smeeding, 1997, s. 633-687; Katz, Autor, 1999, s. 1463-1555; Acemoglu, 2002, s. 781-809; Acemoglu 2003, s. F121-F149; Green et al., 2003, s. 1561-1576]. Postęp technologiczny, promujący wysokie kwalifikacje, a także równoczesna liberalizacja handlu międzynarodowego będą powodować w krajach wysoko rozwiniętych nasilenie się zjawiska wzrostu zapotrzebowania na pracowników o wysokich kwalifikacjach przy jednoczesnym spadku zapotrzebowania na nisko wykwalifikowanych. Jednak podkreśla się, że kraje w których jednocześnie gwałtownie wzrasta powszechny dostęp do edukacji (zarówno w sektorze publicznym, jak i prywatnym) są w znacznie mniejszym stopniu narażone na wzrost rozpiętości dochodowych w wyniku postępu technologicznego, promującego wysokie kwalifikacje [Cornia, Court, 2001, s. 17].

Stopień oddziaływania w równej mierze integracji gospodarczej, liberalizacji handlu, jak i postępu technologicznego, promującego wysokie kwalifikacje, na poziom zróżnicowania dochodów w społeczeństwie jest uzależniony od instytucjonalnych uwarunkowań funkcjonowania rynku pracy, w szczególności zaś od kształtowania się mechanizmów ustalania płac i pozostałych dochodów powiązanych z poziomem płac (jak np. zasiłki dla bezrobotnych i inne transfery socjalne). W przypadku gdy czynniki, 
takie jak: negocjacje zbiorowe w zakresie ustalania płac, mechanizmy indeksacji płac, ustalanie płac minimalnych i poziomu transferów socjalnych w odniesieniu do przeciętnego wzrostu płac w gospodarce, odgrywają istotną rolę, zróżnicowanie płac może mieć znacznie mniejszy zakres niż w sytuacji, gdy mechanizmy te odgrywaja niewielką rolę. Innymi słowy, im płace będą charakteryzowały się większą elastycznością w stosunku do uwarunkowań rynkowych, tym zróżnicowanie tych płac w gospodarce będzie większe. Natomiast, gdy związki zawodowe oraz inne instytucje rynku pracy przyczyniają się do spłaszczenia rynkowej struktury płac, efektem może być wzrost poziomu bezrobocia, zwłaszcza wśród pracowników o niskich kwalifikacjach [Szymańska, 2013, s. 78-92].

\section{Tendencje w zakresie zróżnicowania dochodów}

Większość krajów wysoko rozwiniętych doświadczyła w ciagu ostatnich dwóch dekad wzrostu rozpiętości dochodowych. Ogółem, przeciętny dochód rozporządzalny gospodarstw domowych w krajach OECD wzrastał w tym okresie średnio o 1,7\% rocznie, lecz w większości krajów tempo wzrostu dochodów najbogatszych grup społecznych było znacznie wyższe niż miało to miejsce w grupach o najniższych dochodach, co w rezultacie prowadziło do wzrostu rozpiętości dochodowych. O ile w połowie lat osiemdziesiatych XX wieku przeciętna wartość współczynnika Giniego dla krajów OECD wynosiła 0,29, o tyle w połowie pierwszej dekady XXI wieku wynosiła już 0,316. Na 22 kraje OECD, dla których są dostępne odpowiednio długie szeregi danych, aż w 17 odnotowano wzrost wartości współczynnika Giniego, w tym również w krajach skandynawskich, które tradycyjnie charakteryzuja się stosunkowo niską rozpiętością dochodów [Divided We Stand..., 2011, s. 22]. Zmiany wartości współczynnika Giniego (po uwzględnieniu podatków i transferów) w wybranych krajach OECD w latach 1985-2010 zaprezentowano na rysunku 2.

Jednym z przejawów rosnących rozpiętości dochodowych w krajach OECD jest wzrost udziału w dochodzie grupy $1 \%$ najzamożniejszych obywateli. Udział ten jest bardzo zróżnicowany w poszczególnych krajach, jednakże w większości przypadków jest obserwowana tendencja wzrostowa (rysunek 3.). Największą rozpiętością dochodów pośród krajów wysoko rozwiniętych charakteryzują się Stany Zjednoczone, gdzie w 2010 roku grupa 1\% obywateli o najwyższych dochodach zgromadziła ponad 17\% całkowitego dochodu, oznaczało to ponad dwukrotny wzrost udziału tej grupy w dochodach, w porównaniu z rokiem 1980. Należy zaznaczyć, że jeśli do analizowanych dochodów były włączone dochody z kapitału, udział ten szacowano na 20\% w 2011 roku (i na około $24 \%$ przed wystapieniem kryzysu gospodarczego w 2007 roku) [Alvaredo et al., 2013, s. 2]. Na drugim końcu skali, pod względem koncentracji dochodów wśród najzamożniejszej części społeczeństwa, znajdują się kraje skandynawskie, chociaż, jak już wcześniej wspomniano, również w tych krajach można zauważyć wzrost rozpiętości dochodów. 
RYSUNEK 2.

Wartości współczynnika Giniego (po uwzględnieniu podatków i transferów) w wybranych krajach OECD w latach 1985 i 2010

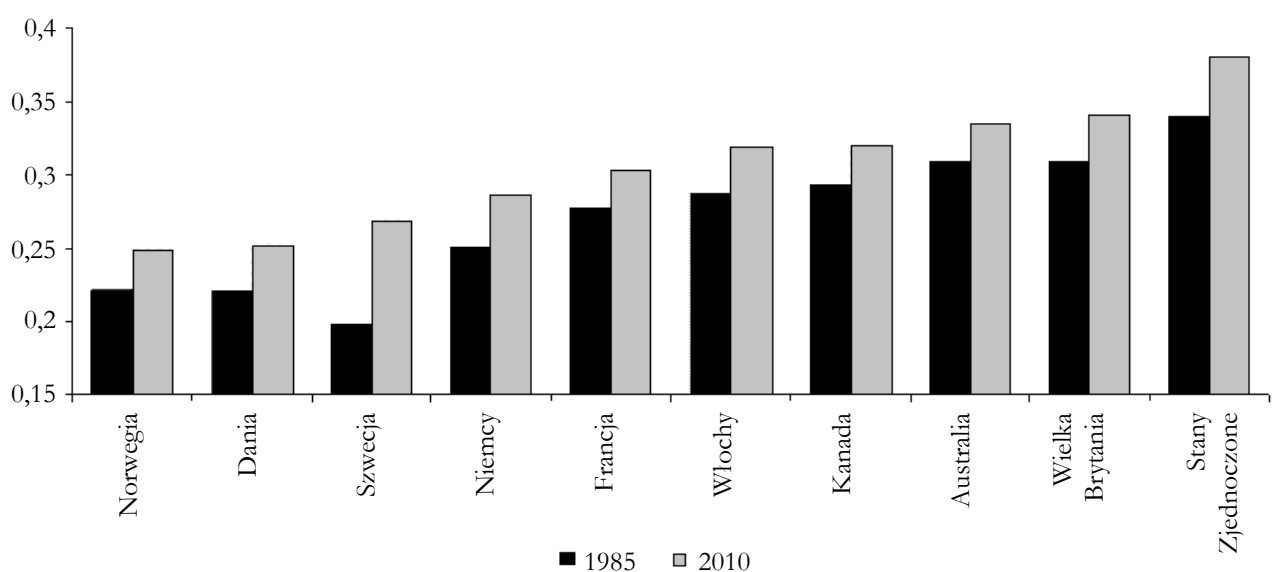

Źródło: opracowanie własne na podstawie danych: [OECD Database on Household Income Distribution and Poverty, dokument elektroniczny, tryb dostępu: http://dx.doi.org/10.1787/ 888932535185, data wejścia: 10.05.2013].

RYSUNEK 3.

Część dochodu przypadająca grupie 1\% najzamożniejszych gospodarstw domowych w wybranych krajach OECD w latach: 1980, 1990, 2000 i 2010

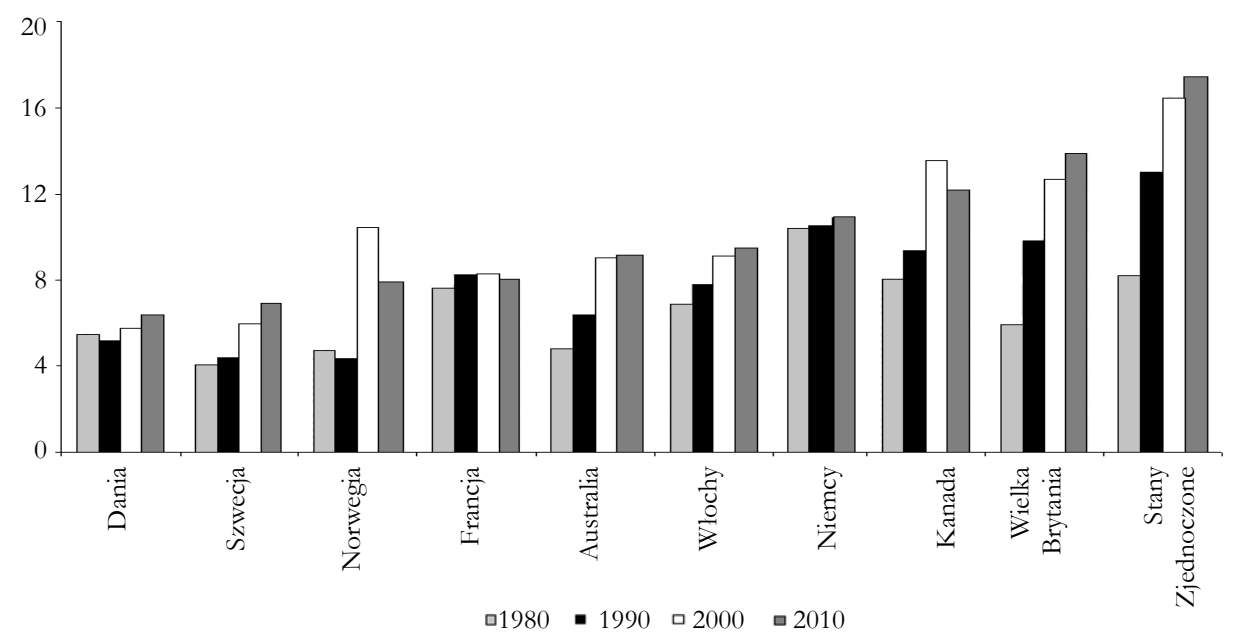

* dla Niemiec ostatnie dostępne dane dotyczą roku 1998

Źródło: opracowanie własne na podstawie danych: [The World Top Incomes Database, dokument elektroniczny, tryb dostępu: http://topincomes.g-mond.parisschoolofeconomics.eu/, data wejścia: 19.07.2013]. 
Analiza zmian wartości podstawowego współczynnika decylowego D9/D1 w latach 2000 i 2010 (rysunek 4.) prowadzi do podobnych wniosków, jak w przypadku wspó1czynnika Giniego. Na 22 kraje OECD, w 14 nastapił wzrost rozpiętości dochodów pomiędzy skrajnymi grupami decylowymi. W 8 krajach tendencja była przeciwna. Do krajów, w których spadek rozpiętości dochodowej był największy, należą: Portugalia, Polska i Węgry. Jednak trzeba zaznaczyć, że analizowany okres objął lata kryzysu gospodarczego, który mógł wywrzeć istotny wpływ na kształtowanie się rozkładu dochodów w społeczeństwie. Ponadto, w poszczególnych krajach wpływ ten mógł mieć zróżnicowany charakter, wobec czego wnioskowanie, dotyczące kierunku długookresowych trendów, jest utrudnione i wymaga dodatkowych analiz.

RYSUNEK 4.

Wartości współczynnika decylowego D9/D1 w wybranych krajach OECD w roku $2010 \mathrm{i}$ zmiana $\mathrm{w}$ stosunku do roku 2000

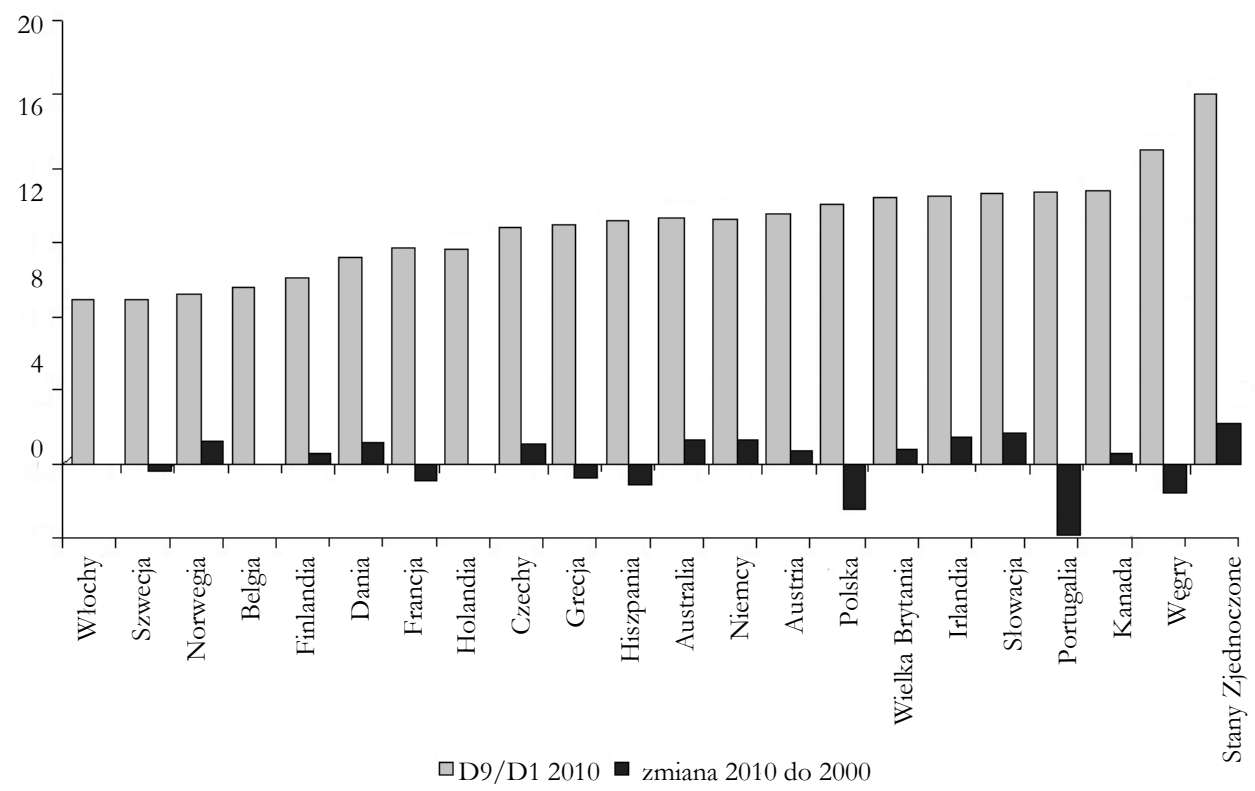

Źródło: opracowanie własne na podstawie danych OECD, dokument elektroniczny, tryb dostępu: [http://stats.oecd.org/index.aspx?, data wejścia: 20.03.2013].

Wyniki badań dotyczących kształtowania się rozpiętości dochodowych w społeczeństwie, zarówno w krajach wysoko rozwiniętych, jak i rozwijających się, wskazują na nieuchronność zjawiska pogłębiania się obserwowanego zróżnicowania pomiędzy warstwami najbogatszymi i najuboższymi. Skłania to badaczy do wysuwania postulatów związanych z potrzeba podejmowania działań w obszarze polityki gospodarczej, które prowadziłyby do ograniczenia wspomnianych nierówności. Jednak postulaty te muszą być wsparte przekonującymi wynikami badań na temat skutków pogłębiania się rozpiętości dochodowych w społeczeństwie. 


\section{Zróżnicowanie dochodów a poziom bezrobocia}

Niezależnie od obserwowanych tendencji w zakresie zróżnicowania dochodów, jak również determinant wzrostu tego zróżnicowania, niejasny pozostaje związek pomiędzy nierównościami dochodowymi w społeczeństwie a efektywnością rynku pracy, przejawiającą się niskim poziomem bezrobocia i wysokim zatrudnieniem. O ile większość ekonomistów zgadza się co do tego, że globalizacja, postęp technologiczny promujący wysokie kwalifikacje oraz instytucjonalne uwarunkowania rynku pracy mają znaczący wpływ na kształtowanie się rozkładu dochodów w społeczeństwie, o tyle, w większości przypadków, nie udaje się potwierdzić hipotezy sformułowanej przez Paula Krugmana. Empiryczna weryfikacja tej hipotezy ma znaczenie z punktu widzenia formułowania rekomendacji pod adresem polityki rynku pracy (oraz polityki społeczno-gospodarczej w ogóle).

Determinanty poziomu zróżnicowania dochodów mogą w różny sposób oddziaływać na poziom bezrobocia. Teoretycznie liberalizacja gospodarki, pozwalająca na uzyskiwanie wyższych dochodów, uruchamia bodźce prowadzące do zwiększenia efektywności. Przede wszystkim w gospodarkach o większej rozpiętości płac (typu collapsing bottom) obserwuje się większe możliwości w zakresie powstawania nowych miejsc pracy niskopłatnej (bezrobocie versus working poor). Pracodawcom opłaca się zatrudniać osoby z niskimi kwalifikacjami, ponieważ koszty związane z zatrudnieniem tych osób są stosunkowo niskie. Z kolei, regulacje rynku pracy, przyczyniające się do zmniejszenie rozpiętości dochodowych, mogą sprzyjać sytuacji, w której ludzie nie mają wystarczająco silnych bodźców do rozwoju zawodowego i zwiększania wydajności pracy [Agell, 2003, s. 35]. Efekt taki występuje w szczególności wówczas, gdy „spłaszczenie” dochodów ma miejsce w grupie pracowników uzyskujących dochody poniżej mediany (gdy występuje wspomniany „efekt akordeonu”). Dodatkowym czynnikiem osłabiającym motywację do pracy jest system pomocy socjalnej, zwłaszcza dla osób bez pracy, który może przyczyniać się do wzrostu oczekiwań co do wysokości akceptowanej płacy.

Jednakże w praktyce dość trudno jest udowodnić tak sformułowane hipotezy. Puhani, testując w swoich badaniach hipotezę Krugmana, podkreśla, iż przeprowadzono stosunkowo niewiele badań na ten temat z wykorzystaniem danych dla poszczególnych krajów [Puchani, 2003, s. 31; Möller, 2009, s. 42]. W większości przypadków nie udało się ustalić pozytywnego (dodatniego) związku pomiędzy stopniem zróżnicowania dochodów w społeczeństwie a poziomem zatrudnienia (lub ujemnego związku pomiędzy stopniem zróżnicowania dochodów w społeczeństwie a poziomem bezrobocia).

W tabeli 1. przedstawiono zestawienie wybranych badań na temat związku pomiędzy zróżnicowaniem dochodów a sytuacją na rynku pracy. Jedynie w jednym przypadku udało się autorom badań potwierdzić istotny związek pomiędzy stopą bezrobocia a dyspersją płac, chociaż również ci autorzy zauważaja, iż wyniki ich badań powinny być traktowane jedynie jako „sugestia”, że taki związek istnieje w rzeczywistości [Bertola et al., 2001, s. 39]. 
TABELA 1. Wyniki wybranych badań na temat związku pomiędzy zróżnicowaniem dochodów a sytuacją na rynku pracy

\begin{tabular}{|l|l|}
\hline Nickell i Bell (1995) & $\begin{array}{l}\text { Nie znaleziono dowodów na to, że w krajach, gdzie obserwowany } \\
\text { wzrost zróżnicowania wynagrodzeń jest stosunkowo mały, obserwuje się } \\
\text { niższe bezrobocie wśród osób o niskich kwalifikacjach. }\end{array}$ \\
\hline Card et al. (1996) & $\begin{array}{l}\text { Nie potwierdzono ujemnej relacji pomiędzy stopa bezrobocia a dysper- } \\
\text { sją płac, porównując rynki pracy w USA, Kanadzie i we Francji. }\end{array}$ \\
\hline OECD (1996) & $\begin{array}{l}\text { Nie wykazano istotnego zwiázku pomiędzy stopa zatrudnienia wśród ni- } \\
\text { sko wykwalifikowanych osób a zakresem występowania niskich płac. }\end{array}$ \\
\hline $\begin{array}{l}\text { Krueger i Pischke } \\
(1997)\end{array}$ & $\begin{array}{l}\text { Nie potwierdzono ujemnej relacji pomiędzy stopa bezrobocia a dysper- } \\
\text { sją płac w odniesieniu do niemieckiego rynku pracy. }\end{array}$ \\
\hline Bertola et al. (2001) & Stwierdzono ujemna relację pomiędzy stopa bezrobocia a dyspersją płac. \\
\hline $\begin{array}{l}\text { Howell i Huebler } \\
(2001)\end{array}$ & $\begin{array}{l}\text { Nie potwierdzono ujemnej relacji pomiędzy stopa bezrobocia a dysper- } \\
\text { sja płac. }\end{array}$ \\
\hline OECD (2004) & $\begin{array}{l}\text { Nie potwierdzono, iż spłaszczona struktura płac w Europie przyczynia } \\
\text { się do wzrostu bezrobocia. Jednakże potwierdzono, że wzrost nierówno- } \\
\text { ści płacowych w USA był spowodowany spadkiem popytu na nisko wy- } \\
\text { kwalifikowanych pracowników. }\end{array}$ \\
\hline
\end{tabular}

Źródło: opracowanie własne na podstawie: [Glyn, 2001, s. 697-713].

W celu weryfikacji analizowanej zależności, dokonano prostego oszacowania empirycznego w postaci wykresów korelacyjnych. Na rysunku 5. przedstawiono zestawienia wartości stóp bezrobocia oraz wartości współczynników decylowych zróżnicowania dochodów dla lat 2000 i 2010, a także zależności pomiędzy dynamiką zmian badanych zmiennych. Wyniki oszacowania nie wskazuja, aby występowała jakakolwiek zależność ujemna pomiędzy zróżnicowaniem dochodów a poziomem bezrobocia i to zarówno w przypadku zróżnicowania dochodów pomiędzy skrajnymi grupami decylowymi, jak i pomiędzy pierwszą grupą decylową a mediana. Podobnie w odniesieniu do dynamiki zmian badanych zmiennych, nie można stwierdzić, żeby wzrost zróżnicowania dochodów przyczyniał się do spadku bezrobocia. Oczywiście, należałoby tego typu badania przeprowadzić z użyciem bardziej zaawansowanych technik badawczych, ale biorąc pod uwagę badania innych autorów, nic nie wskazuje na to, aby mogły one doprowadzić do potwierdzenia hipotezy Krugmana. Z całą pewnością kształtowanie się dochodów ludności ma ścisły związek z uwarunkowaniami funkcjonowania rynku pracy, lecz nie wydaje się uzasadnione rozpatrywanie tego związku w oderwaniu od pozostałych uwarunkowań. Zróżnicowanie dochodów może wywoływać odmienne konsekwencje na rynku pracy, w zależności od tego, jak kształtują się pozostałe czynniki, takie jak: system negocjacji płacowych, system zabezpieczeń socjalnych, opodatkowanie pracy, wymiana handlowa z zagranicą i wiele innych, w tym również pozaekonomicznych. 
RYSUNEK 5.

Zestawienie wartości stóp bezrobocia i wartości współczynników decylowych w wybranych krajach OECD w latach 2000 i 2010
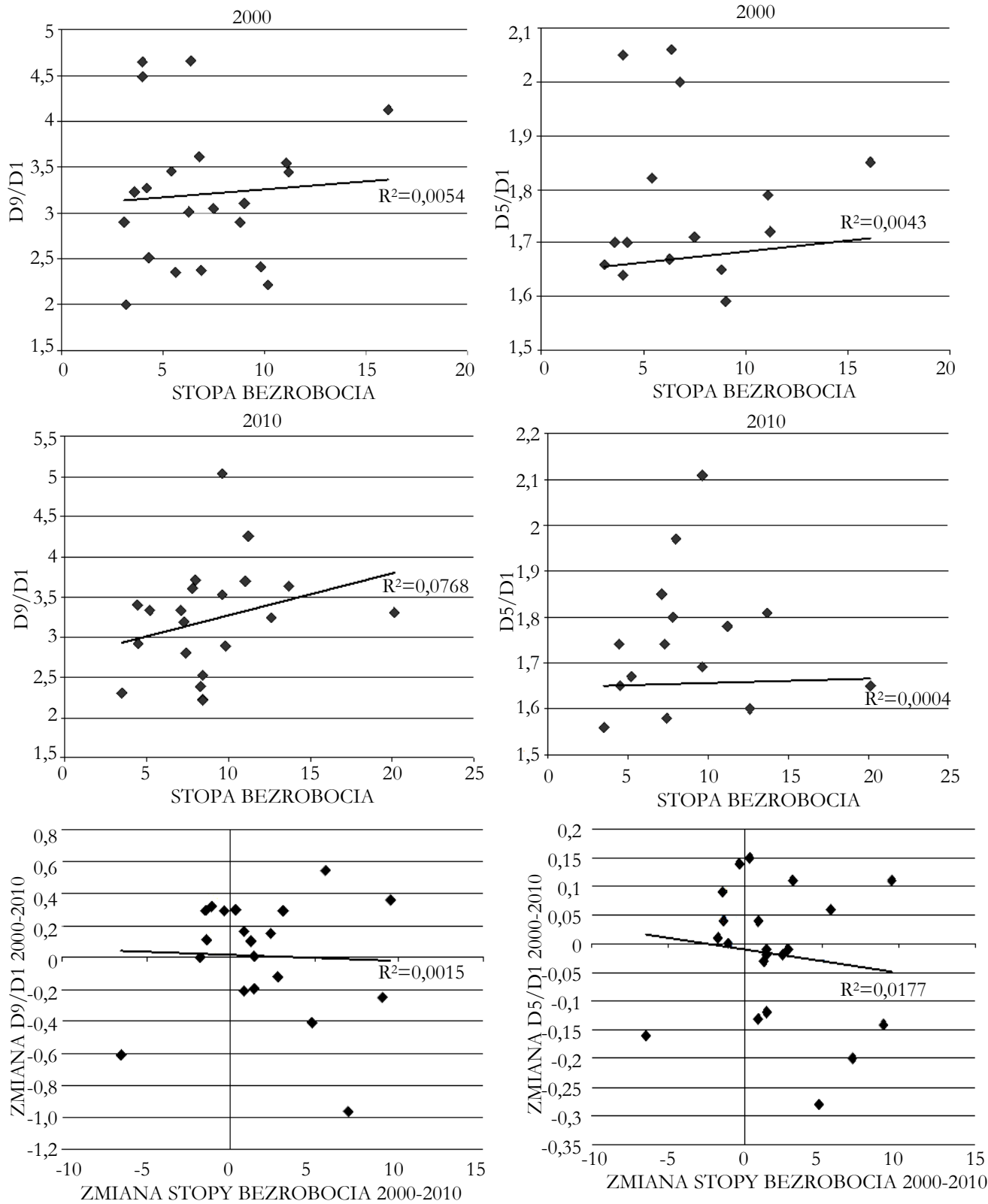

Do sporządzenia rysunków wykorzystano dane dla następującej grupy krajów: Australia, Austria, Belgia, Czechy, Dania, Finlandia, Francja, Grecja, Hiszpania, Holandia, Irlandia, Kanada, Niemcy, Norwegia, Polska, Portugalia, Stany Zjednoczone, Szwecja, Węgry, Wielka Brytania, Włochy.

Źródło: opracowanie własne na podstawie danych OECD, dokument elektroniczny, tryb dostępu: [http://stats.oecd.org/ index.aspx?, data wejścia: 20.03.2013]. 


\section{Podsumowanie}

Hipoteza, zgodnie z którą społeczeństwo musi dokonywać wyboru pomiędzy ograniczaniem nierówności dochodowych a efektywnością rynku pracy, jakkolwiek może być przekonująca w warstwie uzasadnienia teoretycznego, nie znajduje dostatecznego wsparcia w warstwie empirycznej. Watpliwości może budzić zasadność podejmowania badań dotyczących weryfikacji tak sformułowanej hipotezy, bez uwzględniania innych czynników wpływających na warunki funkcjonowania rynku pracy. Nierówności dochodowe mogą bowiem wywoływać różne skutki, w zależności od pozostałych czynników równocześnie występujących w gospodarce. Niektóre z nich moga być trudno mierzalne, jak np. uwarunkowania kulturowe. Niemniej jednak obserwowana, trwała tendencja do wzrostu zróżnicowania dochodów pomiędzy warstwami najbogatszymi a najuboższymi stwarza wyzwanie dla polityki społeczno-gospodarczej w zakresie kreowania instrumentów, które mogłyby ograniczać występujące tendencje.

\section{Literatura}

Acemoglu D. 2002 Directed Technical Change, „Review of Economic Studies”, vol. 67, no. 4. Acemoglu D. 2003 Cross-country Inequality Trends, „Economic Journal”, no. 113. Agell J. 2003 Efficiency and Equality in the Labour Market, CESifo, no. 2.

Alvaredo F., Atkinson A.B., Piketty T., Saez E. 2013 The Top 1 Percent in International and Historical Perspective, National Bureau of Economic Research (NBER), Cambridge MA, Working Paper Series, no. 19075.

Bertola G., Blau F. D., Kahn L. M. 2001 Comparative Analysis of Labor Market Outcomes: Lessons for the US from International Long-Run Evidence, National Bureau of Economic Research (NBER), Cambridge MA, Working Paper Series, no. 8526.

Cornia G.A., Court J. 2001 Inequality, Growth and Poverty in the Era of Liberalization and Globalization, UNU World Institute for Development Economics Research, United Nations University, Helsinki.

Divided We Stand: Why Inequality Keeps Rising 2011, OECD, Paris.

Global Wage Report 2008/09. Minimum Wages and Collective Bargaining: Towards Policy Coherence 2008, International Labour Office, Geneva.

Glyn A. 2001 Inequalities of Employment and Wages in OECD Countries, „Oxford Bulletin of Economics and Statistics", vol. 63, iss. supplement s1.

Gottschalk P., Smeeding T.M. 1997 Cross National Comparison of Earnings and Income Inequality, „Journal of Economic Literature”, vol. 35, no. 2.

Green F., Felstead A., Gallie D. 2003 Computers and the Changing Skill-intensity of Jobs, „Applied Economics”, vol. 35, iss. 14.

Katz L., Autor D. 1999 Changes in the Wage Structure and Earnings Inequality, [in:] Handbook of Labor Economics, O. Ashenfelter, D. Card (eds.), chapter 26, vol. 3A, Elsevier, Amsterdam.

Kremer M., Masking E. 2006 Globalization and Inequality, Working Paper 2008-0087, Weatherhead Center for International Affairs, Harvard University, Cambridge MA. 
Krugman P. 1994 Past and Prospective Causes ob High Unemployment, „Economic Review", vol. 79 , no. 4.

Kuszewski T. 2008 Nierówności ekonomiczne we wspótczesnym świecie. Pomiar i oceny zjawiska, [w:] Wrrost gospodarcay a bezrobocie i nierówności w podziale dochodu, W. Pacho, M. Garbicz (red.), Szkoła Główna Handlowa w Warszawie, Warszawa.

Kwiatkowski E. 2002 Bezrobocie. Podstawy teoretyczne, Wydawnictwo Naukowe PWN, Warszawa.

Makać W., Urbanek-Krzysztofiak D. 2008 Metody opisu statystycznego, Wydawnictwo Uniwersytetu Gdańskiego, Gdańsk.

Möller J. 2009 Wage Dispersion in Germany and the US: Is There Compression from Below?, [in:] Innovation Employment and Growth Policy Issues in the EU and the US, P.J.J. Welfens, J.T. Addison (eds.), Springer - Verlag GmbH, Berlin, London.

OECD Database on Household Income Distribution and Poverty, dokument elektroniczny, tryb dostępu: [http://dx.doi.org/10.1787/888932535185, data wejścia: 10.05.2013].

Okun A.M. 1975 Equality and Efficiency: The Big Tradeoff, The Brookings Institution, Washington D.C.

Portal Statystyczny OECD, dokument elektroniczny, tryb dostępu: [http://stats.oecd.org/ index.aspx?, data wejścia: 20.03.2013].

Puhani P.A. 2003 A Test of the „Krugman Hypothesis” for the United States, Britain, and Western Germany, The Institute for the Study of Labor (IZA), Bonn, „Discussion Paper Series", no. 764.

Szymańska A. 2013 Instytucjonalne uwarunkowania elastyczności rynku pracy w krajach OECD, Wydawnictwo Uniwersytetu Gdańskiego, Gdańsk.

The World Top Incomes Database, dokument elektroniczny, tryb dostępu: [http://topincomes.g-mond.parisschoolofeconomics.eu/, data wejścia: 19.07.2013]. 